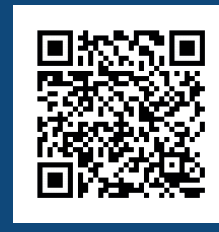

Keywords:

Cedar

Flood conditions

Hypoxia

Antioxidant system Lipid peroxidation

Historic:

Received 22/02/2018 Accepted 13/12/2018

Correspondence: gabiazevedoxd@gmail.com
Gabriela Azevedo Rochala+, Priscila Vasconcellos Romanatti ${ }^{\mathrm{lb}}$, Fabiana Mara Oliveira ${ }^{\mathrm{lc}}$, Antônio Rodrigues da Cunha Netold, Fabricio José Pereirale, Marcelo Pololf

\section{ECOPHYSIOLOGY OF THE TREE SPECIES Cedrela fissilis Vell. (Meliaceae) SUBMITTED TO FLOODING}

ROCHA, G. A.; ROMANATTI, P. V.; OLIVEIRA, F. M.; CUNHA NETO, A. R.; PEREIRA, F. J.; POLO, M. Ecophysiology of the tree species Cedrela fissilis Vell. (Meliaceae) submitted to flooding. CERNE, v. 24, n. 4, p. 323-333, 2018.

\section{HIGHLIGHTS}

Cedrela fissilis trees survived in all treatments due to a marked development of cortical intercellular spaces in flooded plants

The stem periderm thickness was reduced by flooding

The superoxide dismutase activity was decreased, but the activities of the ascorbate perioxidases and catalase in the leaves were increased.

Young Cedrela fissilis trees partially tolerate flooding since they developed ecophysiological changes in order to survive in this condition.

\section{ABSTRACT}

Soil water saturation requires different adaptative strategies by tree species that live under such conditions. We aimed to study the responses that ensure flooding tolerance by tree species and so provide support for recovery projects with degraded areas subject to flooding. We evaluated the ecophysiology of Cedrela fissilis under different water saturations, including anatomical traits, gas exchange parameters, antioxidant system analysis and growth. We subjected I 00 day-old plants to three treatments: Control (FC) where the substrate was kept at field capacity; Flooded Roots (FR), where the substrate remained submerged but with no surface layer of water, and Flooded Stem (FS), with a water layer accumulation of around $3.0 \mathrm{~cm}$ over the substrate, flooding part of the stems. The plants were kept under such conditions for 90 days. Plants survived in all treatments due to a marked development of cortical intercellular spaces in flooded plants. However, photosynthesis and other gaseous exchange were limited under FR and FS treatments. In addition, the periderm thickness was reduce by flooding and there was an accumulation of starch grains in the parenchyma cells of the xylem, cortex and pith of the stem. There was also a significant lipid peroxidation on the leaves under FR and FS treatments. The superoxide dismutase activity was decreased, but the activities of the ascorbate perioxidases and catalase in the leaves were increased. We concluded that young Cedrela fissilis plants partially tolerate flooding since they developed ecophysiological changes in order to survive in this condition. Consequently, this species is a good candidate for the reforestation projects in environments where intermittent flooding occurs, such as riverside and riparian forests.
' Federal University of Alfenas, Alfenas, Miinas Gerais, Brazil - ORCID: 0000-0002-191 I-7204a, 0000-0003-4028$3247^{b}, 0000-0003-0455-7335^{c}, 0000-000$ I-7 I 07-2755 d , 0000-0002-8I32-0625e, 0000-0003- I 865-664 If 


\section{INTRODUCTION}

Climate change has affected the water cycle around the world impacting on the availability of water resources in ecosystems (Marengo et al., 20l I). A great oscillation of water availability is estimated to occur in tropical forests, promoting unusual periods of rainfall which may affect and the occurrence and duration of flooding events (IPCC, 20I4).

In this scenario, in which flooding events are likely to increase, plant life may be impaired once soil water saturation decreases oxygen availability (Loreti et al., 2016). Moreover, since $\mathrm{O}_{2}$ diffusion is 10,000 times lower in water than in saturated air, this reduces oxygen exchange between the atmosphere and the flooded soil (Colmer and Pedersen, 2008; Kreuzwieser and Rennenberg, 2014).

Low oxygen availability may trigger several disorders in plants, such as reduced growth, chlorosis, premature abscission of leaves, decreased water potential and leaf expansion, among other effects and may even, in some cases, result in plant death (Jackson and Colmer, 2005; Medri et al., 2012).

However, there are plants that are capabler of growing in oxygen-deficient soils (De Carvalho Gonçalves et al., 20I3; Voesenek and Bayley-Serres, 20I5). The mechanisms for flooding tolerance are complex and entail a combination of anatomical and physiological changes such as: activation of an anaerobic metabolism, biochemical adjustments and the activation of the antioxidant system (Martizzaro et al., 20 I 3; Polacik and Maricle, 20 I 3; Voesenek and Bailey-Serres, 2015). In addition, flooding causes changes in the biomass allocation among the plants organs and changes in carbohydrate storage (Ferreira et al., 2009), hypertrophy of lenticels, and development of adventitious roots and aerenchyma (Arruda and Colbo, 2004; Medri et al., 2007; Voesenek and Bailey-Serres, 2015).

Although the responses of plants under low oxygen availability conditions are known in general, the tolerance mechanisms vary among species and depend on multiple factors, such as the intensity and length of stress, the plant's age among others (Colmer and Pedersen, 2008; Lira et al., 2013; Kreuzwieser and Rennenberg, 20I4). Moreover, our knowledge of the responses of tree species under flooding is limited compared to herbaceous species (Grandis et al., 2010; Kreuzwieser and Rennenberg, 20I4).

Cedrela fissilis Vell. (Meliaceae), popularly known as pink-cedar, is a woody species native to the Atlantic Rainforest. It presents a wide geographical distribution and develops as an emergent species in primary forests (Oliveira-Filho et al., 2006). In addition, this species can be found in flooded areas (Lorenzi, 1992) and occurs mainly in semi-deciduous seasonal rainforests and mixed ombriophilous forests (Antoniazzi et al., 2013). This plant has been economically importance mainly for timber production, and as a consequence this species has been over/severely exploited, and it now listed in the redbook of threatened species (IUCN, 20I7). Because of its wide distribution in Brazilian forests, and its high value as timber, many reforestation projects make use of $C$. fissilis (Binotto et al., 2016). Thus, it is important to study this species to improve its conservation as well as to provide information on its physiological mechanisms to overcome the flooding condition.

Studies on the ecophysiological events/responses in different water levels might contribute to our knowledge on the floating responses of plant tolerance, may contribute to conservation of this critically endangered species and also to the success of projects that restore areas subject to flooding. We hypothesize that $C$. fissilis has the capacity to tolerate flooding and so has potential to be used in the reforestation of areas with periodic flooding and riparian forest.

In the present work, the tolerance of young $C$. fissilis plants under different water availability was evaluated, in order to analyze the capacity of this species to survive flooding during the initial stages of development and also to evaluate whether survival is due to morphological changes in stem anatomy that facilitate gas exchanges, and in the leaf antioxidant system. It also intended to contribute to the available information about tree species used for restoring degraded areas subject to flooding, in order to guide the success of such environmental projects.

\section{MATERIAL AND METHODS}

\section{Seed collection and plant production}

Seeds of Cedrela fissilis Vell. were obtained through direct collection in areas of secondary forestation at Alfenas, Minas Gerais (21 $255^{\prime 2} 8^{\prime \prime S}$ and 4556'57'O). The seeds were placed on polypropylene trays $(45 \mathrm{~cm}$ $\times 35 \mathrm{~cm} \times 4 \mathrm{~cm}$ ) containing sand and vermiculite in the ratio of $1: 2 \vee v^{-1}$ irrigated to field capacity and kept in a greenhouse until germination. At 100 days after germination, seedlings, which were now, in average, around $4 \mathrm{~cm}$, were transferred to $7.0 \mathrm{~L}$ plastic trays (30 cm diameter $\times 15 \mathrm{~cm}$ depth) containing sand and vermiculite at the ratio of $1: 2 v^{-1}$ as the substrate which were used for the experimental treatments.

Both the seedling culture and the experiment installation were carried in a greenhouse located at the Federal University of Alfenas, Santa Clara campus, Alfenas, Minas Gerais (2 '²5' I 5’S and 4558'56”O). The greenhouse maintained an average internal temperature 
of around $28^{\circ} \mathrm{C}$ (minimum of $13^{\circ} \mathrm{C}$ and maximum of $36^{\circ} \mathrm{C}$ ), the relative air humidity from 55 to $80 \%$ and a maximum radiation intensity of $700 \mathrm{~W} \mathrm{~m}^{-2}$.

\section{Experimental design}

The water treatments wereas follows: Control (FC) where the substrate was kept at the field capacity; Flooded roots (FR), where the substrate remained submerged, however without accumulating water line on its surface, and Flooded stem (FS), in which the trays remained with a layer of water $3.0 \mathrm{~cm}$ above the substrate, flooding part of the seedling stem. Field capacity was determined by weighing I.0 L of the substrate and adding controlled volumes of water until the maximum capacity to water retention without accumulation of water in the bottom of the beaker. The volume of water used was than divided by the volume of the substrate ( 1.0 $\mathrm{L})$ and this proportion was applied to the experiment. The FC was kept with constant irrigation, with no trace of substrate saturation or drought; in a condition similar to the field capacity. Plant nutrition was provided by the application of nutrient solution according to Hoagland and Arnon (1950) to $40 \%$ of ionic strength. Plants were kept in these conditions by 90 days.

The experiment was conducted in randomized block design with three blocks to each treatment, where each block comprised one tray with nine plants so that 27 plants were used per treatment.

\section{Watering System}

The experiment used a watering system that was developed especially for this study (Figure I). This system comprised a stair-shaped metal structure with three steps, where a distinct treatment was allocated to each step. A submerged pump in the tank with a flow capacity of I,000 L.h'-1 (SARLO, São Paulo, Brazil) permitted continuous watering and regular control of the treatments. The pump was connected to the highest level of the system and was also connected to a tank containing nutrient solution. The highest step conserved the Flooded stem (FS) treatment. These trays had two holes drilled $3 \mathrm{~cm}$ above the substrate which were linked via $2 \mathrm{~mm}$ diameter hoses with the trays for the Flooded root (FR) treatment located on the step below. These trays had two holes drilled at substrate level to prevent the accumulation of water above the soil, and the excess water dripped to the trays containing the control treatment (FC) located on the step below. These trays had holes drilled in the bottom to enable an efficient drainage of the solution. Field capacity was checked periodically by weighing the trays. The drained solution of the whole step system was returned to the tank to maintain the cycle.

The control of the level of the nutrient solutions was performed daily while their ionic strength was checked weekly with a conductivity meter MCA-I50 (MS TECNOPON, São Paulo, Brazil). Water or solution was added whenever it was required.

\section{Biometric evaluation}

The biometric evaluations of the $C$. fissilis plants were performed at two periods: on the day of the installation of the experiment and passed 90 days under flooding. The features evaluated were: stem length,

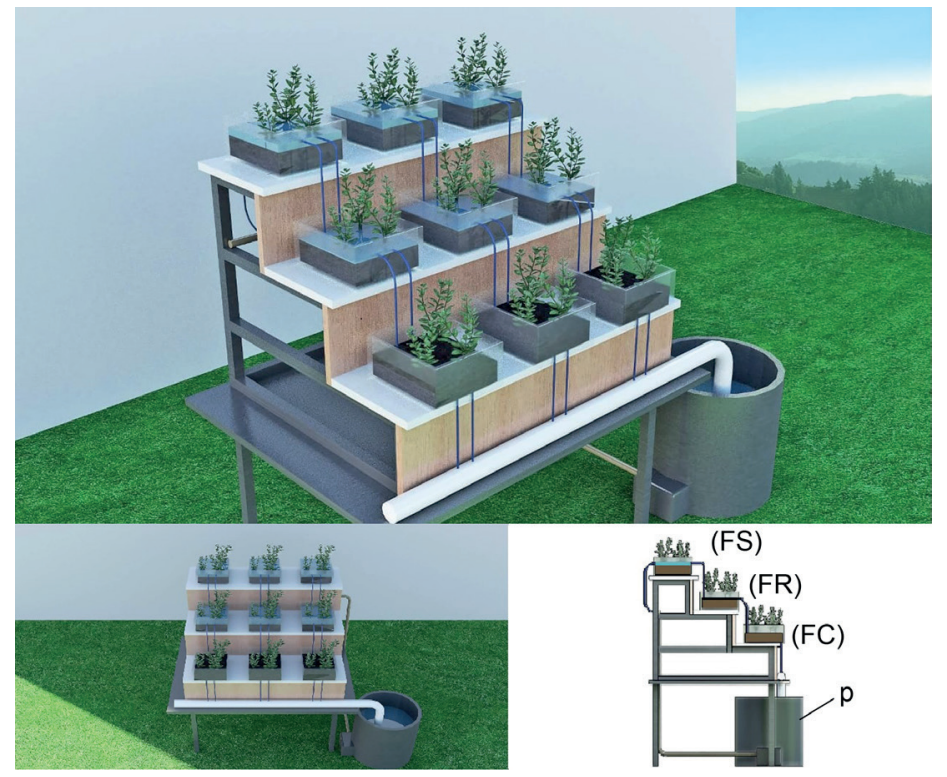

FIGURE I Representation of the experiment layout. FS= flooded stem, FR = flooded roots, $F C=$ control and $p=$ tank and pump. 
measured from the vertical distance between above substrate level the and the top of the stem; and the stem diameter at $3 \mathrm{~cm}$ above substrate level and the number of new leaves was counted.

Stem growth during the course of the experiment, measured to the nearest $1.0 \mathrm{~mm}$, was the difference between the initial and final values. Stem diameter, taken at $3 \mathrm{~cm}$ above the initial stem height, was measured to $0.03 \mathrm{~mm}$ using as digital pachymeter.

Leaf gas exchange analyses

The physiological analyses were performed on the 60 th day after the onset of the experiment, when the plants were already acclimatized and showing fully expanded leaves. The analyses were conducted with an Infra-red gas analyzer (IRGA) model LI-6400XT (LI-COR, Lincoln, USA). All measurements were performed in the morning between 9 and II a.m, on fully expanded and pathogen free leaves, located at third node down from the apical region. Due to the size of the leaves, the measurements were performed on the third leaflet and the area of the cuvette adjusted to $4.8 \mathrm{~cm}^{2}$. The assessed parameters were: photosynthetic rate $(A)$, transpiration rate $(E)$, stomatal conductance (gs) and $\mathrm{CO}_{2}$ intercellular concentration $(\mathrm{Ci})$.

The light response curve was measured and the saturation point of the photosynthetic system was determined, establishing the value for the photosynthetic photon flux density (PPFD) of $500 \mu \mathrm{mol} \cdot \mathrm{m}^{-2} \cdot \mathrm{s}^{-1}$ as the ideal to perform the analyses. The leaf temperature was held at $28^{\circ} \mathrm{C}$ in the cuvette.

\section{Stem anatomy analysis}

At the end of the experiment, stem fragments located around $1.0 \mathrm{~cm}$ above the seedling height were collected and fixed in $\mathrm{FAA}_{70 \%}$ (Johansen, 1940). These samples were dehydrated in an ethanol 70\%, 80\%, $90 \%$ e $100 \%$ series with for 2 hours sequence. Subsequently, the stem fragments were infiltrated with hydroxyethylmethyl acrylate in 100\% ethanol (Leica Microsystems, Wetzlar, Germany) at the proportion of $\mathrm{I}: \mathrm{I}$ and pure activated resin. They were then transferred to histomolds and a hardener was added. After 7 days in the oven at $35^{\circ} \mathrm{C}$, the specimens were removed from histomolds and fixed in wooden blocks which provided a support for the microtomy. Sections at $10 \mu \mathrm{m}$ were cut with a rotary microtome Leica RM 2235 (Leica Microsystems, Wetzlar, Germany). Sections were stained with $1 \%$ toluidine blue for starch, and they were stained with 1\% Lugol (Kraus and Arduin, 1997). Fifteen replicate sections were made for each specimen.

Photomicrography was performed using a digital camera Moticam 2300 (MOTIC, Xiamen, China), attached to a Nikon eclipse E200 microscope (NIKON, São Paulo, Brazil). Anatomical features were measured using the program Image J image analyser.

The anatomical features assessed were: the periderm thickness, percentage of intercellular spaces in the cortex, the sum of the area occupied by sieve tube elements, number of sieve tube elements, pith diameter, average area of the pith cells, total xylem area, vessel element density, percentage of vessel elements, percentage of fibers present in the xylem, number of starch granules per cortical cell, and per pith parenchyma cells and per parenchyma ray cells in the xylem.

\section{Biochemical analyses}

Fully expanded leaves from the third and fourth nodes of the $C$. fissilis plants were sampled after 90 days from the experiment installation. The samples were packed in aluminum foil and stored in a deep freeze at $-80^{\circ} \mathrm{C}$ until the analysis.

Lipid peroxidation was determined according to Buege and Aust (1978); for this purpose, $0.1 \mathrm{~g}$ of plant material was macerated in liquid nitrogen, to which $20 \%$ of PVPP $\left(\mathrm{m} \cdot \mathrm{v}^{-1}\right)$ was added, and homogenized at $1.5 \mathrm{~mL}$ of $20 \%$ trichloroacetic acid $\left(\mathrm{m} \cdot \mathrm{v}^{-1}\right)$. The material was centrifuged at $15.000 \mathrm{~g}$, for 10 minutes. Aliquots $(0.75 \mathrm{~mL})$ of the supernatant were added to $0.75 \mathrm{~mL}$ of thiobarbituric acid (TBA). Thereafter, the tubes were boiled at $90^{\circ} \mathrm{C}$, for 20 minutes and then cooled in an ice bath and the readings were determined in spectrophotometer Biochrom, Libra S22 (Biochrom, Cambridge, England), at $540 \mathrm{~nm}$. The concentration of the complex malondialdehyde / thiobarbituric acid (MDA/TBA) was calculated using the extinction coefficient $1.55 \mathrm{mM} \cdot \mathrm{cm}^{-1}$.

To obtain protein extracts for the analysis antioxidant enzyme activity, $200 \mathrm{mg}$ of leaf were macerated in liquid nitrogen and homogenized with I.5 $\mathrm{mL}$ of extraction buffer. The homogenized materials were centrifuged at $12.000 \mathrm{~g}$, for 30 minutes, at $4^{\circ} \mathrm{C}$. The supernatant was collected and used in the analyses of superoxide dismutase (SOD), catalase (CAT), ascorbate peroxidase (APX) activities according to Biemelt at al. (1998). Protein content was determined by the method of Bradford (1976) using bovine serum albumin as the standard, and the enzymatic activities were calculated following García-Limones et al. (2002).

Superoxide dismutase activity (SOD) was determined by the capability of the enzyme to inhibit the reduction of nitro blue tetrazolium (NBT) in the presence of riboflavin. The tube containing the blank (incubation method without the sample) and the tubes with the phosphate buffer at $50 \mathrm{mM}$ and $\mathrm{pH}$ 7.8, EDTA 0.I Mm, methionine $13 \mathrm{mM}, 7.5 \mu \mathrm{M}$ of NBT, riboflavin 
$2 \mathrm{mM}$ together with $20 \mu \mathrm{L}$ of sample, were illuminated with fluorescent lighting of $20 \mathrm{~W}$ for 12 minutes. Afterwards, readings were performed at $560 \mathrm{~nm}$ in spectrophotometer. The SOD activity was established by the amount of enzyme that inhibits $50 \%$ of the reduction rate of NBT (Giannopolitis and Ries, 1977).

Catalase activity (CAT) was determined by the decreased absorbance at $240 \mathrm{~nm}$, every 15 seconds for 3 minutes, monitored by the consumption of hydrogen peroxide. The reaction medium was comprised of phosphate buffer $50 \mathrm{mM}, \mathrm{pH} 7.0,20 \mathrm{mM}$ of $\mathrm{H}_{2} \mathrm{O}_{2}$ and 50 $\mu \mathrm{L}$ of enzyme extract. The reaction was started by adding $\mathrm{H}_{2} \mathrm{O}_{2}\left(\varepsilon=36 \mathrm{mM}^{-1} \cdot \mathrm{cm}^{-1}\right)$. The CAT activity was defined by the consumption of $\mathrm{H}_{2} \mathrm{O}_{2}$ (Beers and Sizer, 1952).

Ascorbate peroxidase (APX) activity was determined by the decreased absorbance at $290 \mathrm{~nm}$ due to the consumption of ascorbate $\left(\varepsilon=2.8 \mathrm{~m} \cdot \mathrm{M}^{-1} \cdot \mathrm{cm}^{-1}\right)$ at every 15 seconds during 3 minutes. The reaction medium was comprised of phosphate buffer $50 \mathrm{mM}, \mathrm{pH} 7.0$, sodium ascorbate $0.25, \mathrm{mM}, \mathrm{H}_{2} \mathrm{O}_{2} 5 \mathrm{mM}$ and $50 \mu \mathrm{L}$ of enzymatic extract. The APX activity was defined by the consumption of ascorbic acid (Nakano and Asada, 198I).

Statistical analysis

Data submitted to a Shapiro-Wilk normality test $(\alpha=0.05)$ showed normal distribution. They were then subjected to the variance analysis (ANOVA), followed by the Tukey's test for the comparison of the means at $5 \%$ of significance, in SISVAR software, version 5.6.

\section{RESULTS}

\section{Biometrics}

All $C$. fissilis plants survived for the experimental period of 90 days, regardless the treatment. However, C. fissilis plants grown under flooding showed significant decrease in shoot growth with a $44 \%$ decrease of this variable in the FR treatment and $64 \%$ for plants of FS treatment. On the other hand, flooding did not affected the stem diameter (Table I). In addition, the development of new leaves was diminished by flooding conditions (Table I).

\section{Leaf gas exchange}

Cedrela fissilis under flooding conditions showed lower net photosynthesis and stomatal conductance as well as lower intercellular $\mathrm{CO}_{2}$ concentration. The FR treatment reduced the photosynthetic rate by $26 \%$ whereas the FS reduced this variable by $46 \%$ as compared to FC treatment. However, the transpiratory rate did not show significant changes (Table 2).
TABLE I Biometrics of Cedrela fissilis (Meliaceae) subjected to flooding. Data are shown as the means \pm standard deviation.

\begin{tabular}{cccc}
\hline Variables & $\begin{array}{c}\text { Control } \\
(\mathrm{FC})\end{array}$ & $\begin{array}{c}\text { Flooded roots } \\
(\mathrm{FR})\end{array}$ & $\begin{array}{c}\text { Flooded stem } \\
(\mathrm{FS})\end{array}$ \\
\hline $\begin{array}{c}\text { Shoot growth } \\
(\mathrm{cm})\end{array}$ & $6.3 \pm 3.0 \mathrm{a}$ & $3.5 \pm 1.0 \mathrm{~b}$ & $2.3 \pm 1.3 \mathrm{~b}$ \\
$\begin{array}{c}\text { Stem diameter } \\
(\mathrm{mm})\end{array}$ & $1.9 \pm 0.9 \mathrm{a}$ & $2.6 \pm 1.2 \mathrm{a}$ & $2.3 \pm 1.1 \mathrm{a}$ \\
$\begin{array}{c}\text { Number of new } \\
\text { leaves }\end{array}$ & $3.1 \pm 1.4 \mathrm{a}$ & $2.3 \pm 1.5 \mathrm{~b}$ & $1.9 \pm 0.7 \mathrm{~b}$ \\
\hline
\end{tabular}

*Means followed by the same letter in the rows did not differ by the Tukey's test $(p<0.05)$.

TABLE 2 Leaf gas exchange of Cedrela fissilis (Meliaceae) subjected to flooding. Net photosynthesis (A), stomatal conductance (gs), concentration of intercellular $\mathrm{CO}_{2}(\mathrm{Ci})$, transpiratory rate $(\mathrm{E})$. Data are shown as the means \pm standard deviation.

\begin{tabular}{|c|c|c|c|}
\hline Variables & $\begin{array}{l}\text { Control } \\
\text { (FC) }\end{array}$ & $\begin{array}{l}\text { Flooded roots } \\
\text { (FR) }\end{array}$ & $\begin{array}{l}\text { Flooded Stem } \\
\text { (FS) }\end{array}$ \\
\hline$\frac{\mathrm{A}}{\left(\mu \mathrm{mol} \cdot \mathrm{CO}_{2} \cdot \mathrm{m}^{-2} \cdot \mathrm{s}^{-1}\right)}$ & $3.8 \pm 1.0 \mathrm{a}$ & $2.8 \pm 0.7 b$ & $2.1 \pm 0.4 b$ \\
\hline $\begin{array}{c}\text { gs } \\
\left(\mathrm{mol} \cdot \mathrm{H}_{2} \mathrm{O} \cdot \mathrm{m}^{-2} \cdot \mathrm{s}^{-1}\right)\end{array}$ & $0.06 \pm 0.01 \mathrm{a}$ & $0.04 \pm 0.01 b$ & $0.03 \pm 0.004 b$ \\
\hline $\begin{array}{c}\mathrm{Ci} \\
\left(\mathrm{mmol} \cdot \mathrm{mol}^{-1}\right)\end{array}$ & $27 \mid .5 \pm 13.5 \mathrm{a}$ & $240 \pm 15.2 b$ & $236.2 \pm 10.7 b$ \\
\hline $\begin{array}{c}\mathrm{E} \\
\left(\mathrm{mmol} \cdot \mathrm{H}_{2} \mathrm{O} \cdot \mathrm{m}^{-2} \cdot \mathrm{s}^{-1}\right)\end{array}$ & $1.94 \pm 0.7 \mathrm{a}$ & $1.88 \pm 0.8 \mathrm{a}$ & $2.03 \pm 1.1 \mathrm{a}$ \\
\hline
\end{tabular}

Means followed by the same letter in the rows did not differ by the Tukey's test $(\mathrm{p}<0.05)$.

\section{Stem anatomy}

The thickness of the periderm was significantly reduced in the FR and FS treatments (Table 3 and Figure 2). In addition, flooding increased the percentage of cortical intercellular spaces (Table 3 and Figure 2), such that in the plants of FS treatment the percentage of intercellular spaces was up to six times greater as compared to FC treatment (Table 3 and Figure 2).

The sum of the area of sieve tube elements in the phloem was not significantly modified by the treatments. However, a decreased number of the sieve tube elements was found in the FR and FS treatments (Table 3 and Figure 2).

Flooding did not influence on the pith diameter but did decrease the size of the pith cells by $30 \%$ in the FR treatment and by $35 \%$ for the FS plants as compared to control (Table 3 and Figure 2).

There was an increase in the proportion of vessel elements and ray parenchyma in xylem for the plants under flooding (Table 3). In addition, the proportion of fibers in the xylem decreased in the FR and FS treatments. 
TABLE 3 Stem anatomical traits of Cedrela fissilis (Meliaceae) subjected to flooding. Data are shown as the means \pm standard deviation.

\begin{tabular}{|c|c|c|c|}
\hline Variables & $\begin{array}{l}\text { Control } \\
\text { (FC) }\end{array}$ & $\begin{array}{l}\text { Flooded } \\
\text { roots } \\
(\mathrm{FR})\end{array}$ & $\begin{array}{c}\text { Flooded } \\
\text { stem } \\
(\mathrm{FS})\end{array}$ \\
\hline $\begin{array}{l}\text { Periderm thickness } \\
\qquad(\mu \mathrm{m})\end{array}$ & $\begin{array}{r}107.8 \\
\pm 28.2 \mathrm{a}\end{array}$ & $\begin{array}{r}92.22 \\
\pm 31.1 \mathrm{~b}\end{array}$ & $\begin{array}{r}85.38 \\
\pm 26.9 \mathrm{~b}\end{array}$ \\
\hline $\begin{array}{l}\text { Proportion of cortical } \\
\text { intercellular spaces } \\
\text { (\%) }\end{array}$ & $\begin{array}{c}0.77 \\
\pm 0.4 \mathrm{~b}\end{array}$ & $\begin{array}{c}3.97 \\
\pm 1.9 \mathrm{a}\end{array}$ & $\begin{array}{c}4.64 \\
\pm 1.6 \mathrm{a}\end{array}$ \\
\hline $\begin{array}{l}\text { Area of the sieve tube elements } \\
\qquad\left(\mu \mathrm{m}^{2}\right)\end{array}$ & $\begin{array}{l}439.46 \\
\pm 99.9 \mathrm{a}\end{array}$ & $\begin{array}{l}410.53 \\
\pm 91.3 \mathrm{a}\end{array}$ & $\begin{array}{r}349.99 \\
\pm 112.1 \mathrm{a}\end{array}$ \\
\hline Number of sieve tube elements & $\begin{aligned} & 17 \\
\pm & 3.2 \mathrm{a}\end{aligned}$ & $\begin{aligned} & 14 \\
\pm & 5.2 \mathrm{~b}\end{aligned}$ & $\begin{aligned} & 9 \\
& \pm 1.8 \mathrm{c}\end{aligned}$ \\
\hline $\begin{array}{c}\text { Proportion of vessel elements } \\
\text { (\%) }\end{array}$ & $\begin{aligned} & 2.7 \\
\pm & 0.7 c\end{aligned}$ & $\begin{array}{l}3.5 \pm \\
0.8 \mathrm{~b}\end{array}$ & $\begin{array}{r}5 \pm \\
\mathrm{I} a\end{array}$ \\
\hline $\begin{array}{l}\text { Diameter of vessel elements } \\
\qquad\left(\mu \mathrm{m}^{2}\right)\end{array}$ & $\begin{array}{l}35.1 \\
\pm \\
\pm .4 \mathrm{~b}\end{array}$ & $\begin{array}{r}48.5 \pm \\
6.1 \mathrm{a}\end{array}$ & $\begin{array}{c}35.7 \pm \\
4.8 b\end{array}$ \\
\hline $\begin{array}{c}\text { Proportion of fibers in the xylem } \\
\text { (\%) }\end{array}$ & $\begin{array}{r}90.7 \\
\pm 2,2 \mathrm{a}\end{array}$ & $\begin{aligned} & 87.6 \\
\pm & 2.8 \mathrm{~b}\end{aligned}$ & $\begin{array}{r}82.6 \\
\pm 5.4 \mathrm{c}\end{array}$ \\
\hline $\begin{array}{l}\text { Proportion of parenchyma rays } \\
\text { (\%) }\end{array}$ & $\begin{aligned} & 6.6 \\
\pm & 2.2 \mathrm{c}\end{aligned}$ & $\begin{aligned} & 8.9 \\
\pm & 2.6 \mathrm{~b}\end{aligned}$ & $\begin{aligned} & 12.4 \\
\pm & 3.3 \mathrm{a}\end{aligned}$ \\
\hline Diameter of the pith & 505.64 & 420.75 & 474.44 \\
\hline$(\mu \mathrm{m})$ & $\pm 142.9 \mathrm{a}$ & $\pm 141.9 \mathrm{a}$ & $\pm 64.5 \mathrm{a}$ \\
\hline $\begin{array}{l}\text { Average area pith cells } \\
\qquad\left(\mu \mathrm{m}^{2}\right)\end{array}$ & $\begin{array}{r}1488.55 \\
\pm 589.4 \mathrm{a}\end{array}$ & $\begin{array}{l}1040.78 \\
\pm 386.6 \mathrm{~b}\end{array}$ & $\begin{array}{r}955.17 \\
\pm 991.7 \mathrm{~b}\end{array}$ \\
\hline
\end{tabular}

*Means followed by the same letter in the rows did not differ by the Tukey's test $(\mathrm{p}<0.01$.
However, the diameter of vessel elements increased for FR plants (Table 3).

The amount of starch grains in the parenchyma of the cortex decreased only for the FR plants (Table 4 and Figure 3). However, the highest number of starch grains was observed in the FS treatment, followed by the FR, with the lowest mean found for the FC treatment (Table 4 and Figure 3). Likewise, in the xylem rays, there was an increase in the number of starch grains for the plants of FS treatment (Table 4 and Figure 3).

\section{Biochemical analyses}

Plants from the FS treatment showed the highest lipid peroxidation followed by the FR plants, whilst those of the FC treatment showed the lowest values (Table $5)$. The activity of the antioxidant system enzymes of $C$. fissilis showed significant differences under flooding (Table $5)$. The SOD activity was reduced in the plants of FR and FS treatments as compared to the control. CAT activity increased only in the FS treatment whereas the APX activity increased in both flooding conditions (Table 5).

\section{DISCUSSION}

C. fissilis plants partially tolerate flooding and we have shown they have physiological, anatomical

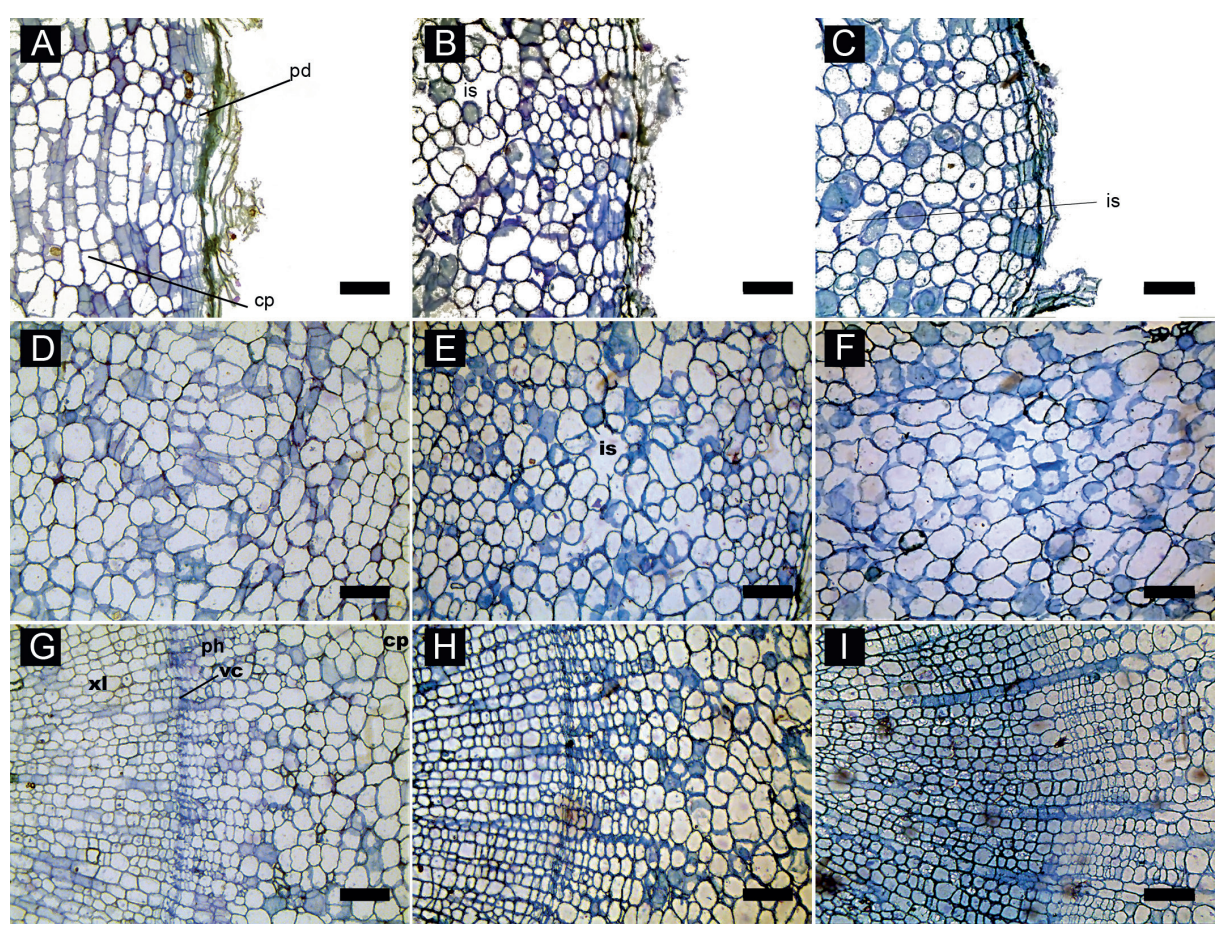

FIGURE 2 Anatomy of the Cedrela fissilis (Meliaceae) stem grown under different water regimes. Control (FC) treatment (A, $D$ and $G)$, flooded root (FR) treatment (B, E and $H)$, flooded stem (FS) treatment (C, $F$ and $I)$. Transverse sections of the regions containing the periderm ( $A, B$ and $C$ ), the cortical parenchyma $(D, E$ and $F)$, and the vascular tissues $(\mathrm{G}, \mathrm{H}$ and $\mathrm{I}) \cdot \mathrm{pd}=$ periderm, $\mathrm{cp}=$ cortical parenchyma, is = intercellular space, $\mathrm{ph}=\mathrm{phloem}, \mathrm{xl}=\mathrm{xylem}, \mathrm{vc}=$ vascular cambium. Bars $=100 \mu \mathrm{m}$. 
TABLE 4 Accumulation of starch in the cortex, xylem and pith cells in the stems of Cedrela fissilis (Meliaceae) subjected to flooding. Data are shown as the means \pm standard deviation.

\begin{tabular}{cccc}
\hline $\begin{array}{c}\text { Variables } \\
(\mathrm{FC})\end{array}$ & Control & $\begin{array}{c}\text { Flooded } \\
\text { root } \\
(\mathrm{FR})\end{array}$ & $\begin{array}{c}\text { Flooded } \\
\text { stem } \\
(\mathrm{FS})\end{array}$ \\
\hline $\begin{array}{c}\text { Number of starch grains per } \\
\text { cortical parenchyma cell }\end{array}$ & $6 \pm 2.7 \mathrm{a}$ & $4 \pm 2.3 \mathrm{~b}$ & $6 \pm 3.4 \mathrm{a}$ \\
$\begin{array}{c}\text { Number of starch grains per pith } \\
\text { parenchyma cell }\end{array}$ & $7 \pm 3.1 \mathrm{c}$ & $10 \pm 3.9 \mathrm{~b}$ & $13 \pm 5.9 \mathrm{a}$ \\
$\begin{array}{c}\text { Number of starch grains in cells } \\
\text { of xylem rays }\end{array}$ & $5 \pm 2 \mathrm{~b}$ & $5 \pm 3 \mathrm{~b}$ & $5.5 \pm 2 \mathrm{a}$ \\
\hline
\end{tabular}

*Means followed by the same letter in the rows did not differ by the Tukey's test $(p<0.01)$.

TABLE 5 Responses of the antioxidant system enzymes and lipid peroxidation in the leaves of Cedrela fissilis (Meliaceae) subjected to flooding. SOD: superoxide dismutase, CAT: catalase, APX: ascorbate peroxidase. Data are shown as the means \pm standard deviation.

\begin{tabular}{cccc}
\hline Variables & $\begin{array}{c}\text { Control } \\
(\mathrm{FC})\end{array}$ & $\begin{array}{c}\text { Flooded } \\
\text { root } \\
(\mathrm{FR})\end{array}$ & $\begin{array}{c}\text { Flooded } \\
\text { stem } \\
(\mathrm{FS})\end{array}$ \\
\hline Lipid peroxidation $(\mathrm{mmol}$ of MDA & $\begin{array}{c}489.2 \\
\pm 29.1 \mathrm{c}\end{array}$ & $\begin{array}{c}1352.7 \\
\pm 108 \mathrm{~b}\end{array}$ & $\begin{array}{c}1568.8 \\
\pm 100 \mathrm{a}\end{array}$ \\
$\left.\mathrm{g}^{-1} \cdot \mathrm{MF}\right)$ & 33.53 & 13.4 & 9.8 \\
$\mathrm{SOD}\left(\mathrm{U} \mathrm{mg}{ }^{-1}\right.$ protein $)$ & $\pm 11.7 \mathrm{a}$ & $\pm 5.9 \mathrm{~b}$ & $\pm 3.5 \mathrm{~b}$ \\
$\mathrm{CAT}\left(\mu \mathrm{mol} \mathrm{H}_{2} \mathrm{O}_{2} \mathrm{~min}^{-1} \cdot \mathrm{mg}^{-1}\right.$ & 16.7 & 23.6 & 36.5 \\
$\mathrm{protein}^{2}$ & $\pm 3.9 \mathrm{~b}$ & $\pm 2.5 \mathrm{~b}$ & $\pm 3.6 \mathrm{a}$ \\
APX $\left(\mu \mathrm{mol}\right.$ ascorbate $\mathrm{min}^{-1} \cdot \mathrm{mg}^{-1}$ & 87.3 & 161.7 & 191.5 \\
protein $)$ & $\pm 13.8 \mathrm{~b}$ & $\pm 34.9 \mathrm{a}$ & $\pm 24.6 \mathrm{a}$ \\
\hline
\end{tabular}

*Means followed by the same letter in the rows did not differ by the Tukey's test $(\mathrm{p}<0.01)$. and biochemical modifications which enabled them to survive under flooding despite some photosynthesis and growth limitations. The main adaptation of this species to overcome flooding may be the development of a higher proportion of cortical intercellular spaces, which were to be some 5 to 6 times greater in the stems of flooded plants. Intercellular spaces are known to enhance porosity of the tissue and thus, they contribute significantly to the diffusion of gases, mainly oxygen, between submerged organs and not submerged ones (Voesenek and Bailey-Serres, 2015; Oliveira et al., 2015; Loreti et al., 2016). It is likely, therefore, that intercellular spaces minimized the most acute harm regarding oxygen deficit and enabled the plants to survive.

However, flooded plants of $C$. fissilis showed some limitation to leaf gas exchange that affected photosynthesis and growth. A decrease up to $50 \%$ in stomatal conductance in plants from FS treatment, indicated that under flooding conditions, $C$. fissilis plants closed their stomata, promoting a stomatal limitation to photosynthesis. The lower means for the intercellular carbon concentrations in flooded plants supports this view. Moreover, many studies have shown the relation between stomatal conductance and carbon sequestration in flooded plants (Liao and Lin, 200I; Mielke et al., 2003; Striker, 2012) and so support the view that the stomatal closing may limit photosynthesis. However, the mechanism that reduces the stomatal conductance under flooding is poorly understood (Kreuzwieser and Rennernberg, 20I4). According to Striker (2012) the
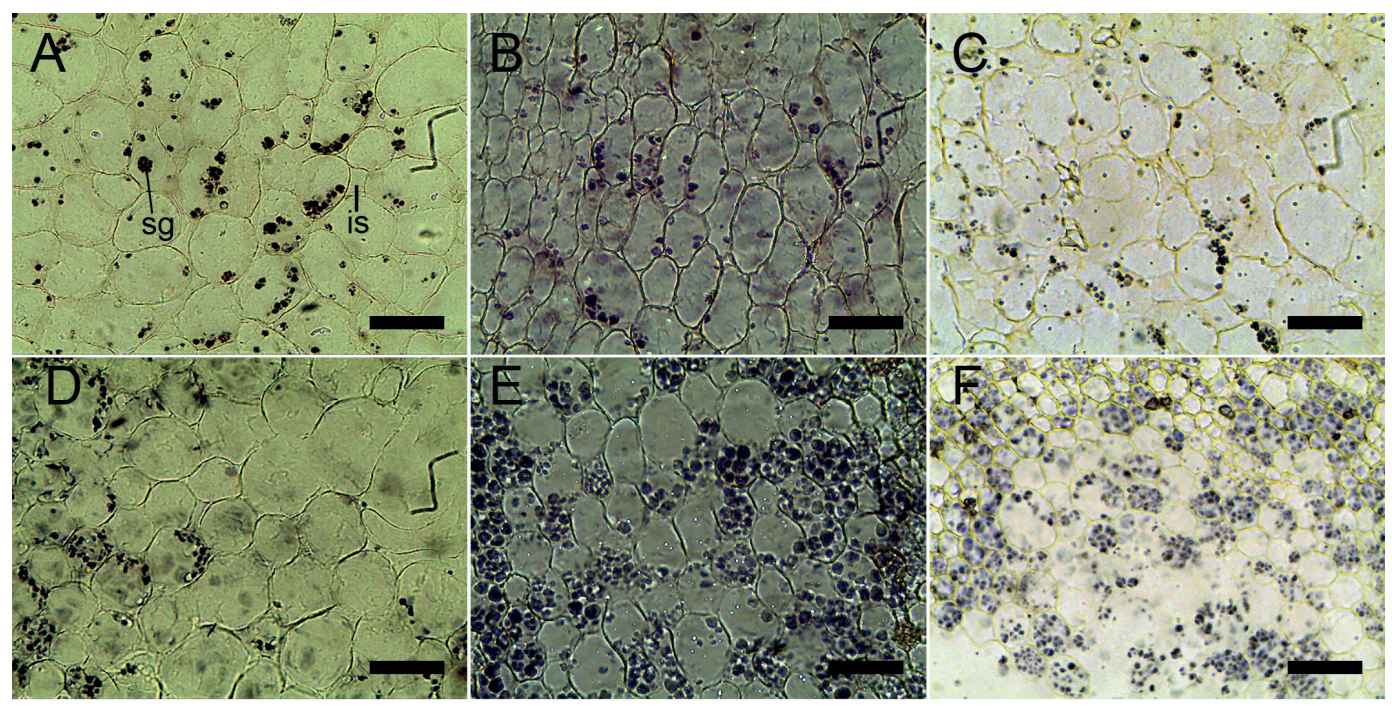

FIGURE 3 Anatomy of the Cedrela fissilis (Meliaceae) stem grown under different water regimes. Control (FC) treatment (A, $D$ and $G)$, flooded root (FR) treatment (B, E and $H)$, flooded stem (FS) treatment (C, $F$ and $I)$. Transverse sections of the regions containing the periderm ( $A, B$ and $C)$, the cortical parenchyma $(D, E$ and $F)$, and the vascular tissues $(\mathrm{G}, \mathrm{H}$ and $\mathrm{I}) \cdot \mathrm{pd}=$ periderm, $\mathrm{cp}=$ cortical parenchyma, is = intercellular space, $\mathrm{ph}=$ phloem, $\mathrm{xl}=\mathrm{xylem}, \mathrm{vc}=$ vascular cambium. Bars $=100 \mu \mathrm{m}$.. 
stomatal closing promoted by flooding prevents the leaf dehydration. However, limitation of the stomatal conductance may occur even without reduction in the leaf water potential by the abscisic acid ( $A B A)$ signalling (Jackson et al., 2002). It is possible that the stomatal closing in $C$. fissilis happened through ABA effect, when transpiration remained unaffected by flooding.

The reduction in photosynthesis in flooded $C$. fissilis may explain the significant reduction in new leaf formation and the limited elongation of the stem. It is well known that plants submitted to oxygen deficiency (hypoxia), and also those which show damage photosynthesis, reduce the allocation of energy destined to growth and move it to basic metabolism in order to survive (Kolb et al., 1998; Grandis et al., 2010; Medri et al., 2012; Coelho et al., 20l4).

The anatomical changes in $C$. fissilis under flooding treatments support the conclusion that water saturation harmed the development of the species. It is notable that the density of sieve tube elements in the phloem decreased by around $50 \%$ in plants of the FS treatment. In addition, the maintenance of the size of the sieve tube elements associated with this reduction in number, suggest that the flow of photo-assimilates through phloem was impaired. Furthermore, the limitation of the phloem transport may have harmed the translocation of carbohydrates from leaves to roots as well as the other sinks, negatively affecting the development of such organs. Similar results were shown by Souza et al. (2010). This effect is supported by the reduced number of new leaves produced by the plants under flooding (which depends on shoot apical meristem activity and photoassimilates).

The decrease in periderm thickness in $C$. fissilis under flooding may also be related to a lower radial transport of photoassimilates from the phloem through the cortex, which was impaired by the decreased phloem development and the excess of intercellular spaces in this region. However, the thinner periderm may have contributed to a greater diffusion of oxygen from the atmosphere to plant's inner tissues providing benefit to plants during long periods of flooding (Voesenek \& Bailey-Serres, 2015).

The limitation in phloem transport is corroborated by the data for starch accumulation presented. This carbohydrate accumulation was found to have a higher intensity in the innermost tissues of the stem, such as in the xylem parenchyma rays and in the pith. This supports the view that the accumulation of starch in the organs may be linked to the impairment of phloem flow (Ferner et al. 2012).

Modifications found in the xylem also help us to understand the tolerance mechanisms of $C$. fissilis to flooding since we observed a greater density of vessel elements in both flooded treatments. Vessel elements can show special features which enables the transport huge amounts of water (Severo et al., 2017). In addition, larger vessel diameter and density may increase the xylem water conductivity in trees (Garcia-Cervigon et al., 20l8). Our results indicate that despite suffering from a water saturation, the efficacy of water transport was regulated in C. fissilis, maintaining the hydraulic conductivity in flooded plants. Effective hydraulic conductivity, conferred by changes in xylem, might also explain the unchanged transpiration rate (Sperry and Pockman, 1993). The maintenance of such hydraulic conductivity is important since flooding can decrease water absorption by plants (Coutts, 198I; Kreuzwieser and Rennernberg, 2014).

The increase of parenchymatous rays in flooded treatments enabled the higher allocation of starch granules in flooded plants. Although a lower input for fibers on the tissue was observed, this decrease in fibers did not affect the plant's stability. The overall anatomical response observed in $C$. fissilis favoured gaseous diffusion through intercellular spaces, which is an important feature under flooding conditions (Jackson et al., 2009; Loreti et al., 2016).

We observed that the action of the antioxidant system in the leaves of $C$. fissilis was not sufficient to avoid flooding stress since lipid peroxidation increased around $300 \%$ in flooded plants. Various studies have shown that under flooding conditions plants trigger the production and accumulation of reactive $\mathrm{O}_{2}$ species (ROS), which may harm cell membranes through lipid peroxidation and thus impairs cell metabolism (Mittler, 2002; Boamfa et al., 2005; Larré et al., 20I3; Messchmidt et al., 20I5).

In order to avoid ROS accumulation, plants have enzymatic and non-enzymatic defense systems that enables the scavenging of these compounds and so protecting against the oxidative stress (Larré et al., 20l6). Flooding triggers the activation such an antioxidant system in $C$. fissilis leaves, although the enzymatic activities were not sufficient to eliminate the oxidative stress, as evinced by lower SOD activity shown by flooded plants. Similar results were found by Larré et al. (2013) in Erythrina crista-galli plants under water saturation, and the authors proposed that low SOD activity is related to lower production of the superoxide $\left(\mathrm{O}_{2}^{-}\right)$. The increase of more than $100 \%$ in the CAT activity in C. fissilis plants from the FS treatment, as well as that of APX activity in 
plants under both levels of flooding (FR and FS), indicate that unlike the lower superoxide production, these plants showed high hydrogen peroxide $\left(\mathrm{H}_{2} \mathrm{O}_{2}\right)$ levels.

High APX and CAT activities demonstrate the formation of ERO in C. fissilis when flooded, although the increase of antioxidant enzymatic activity was not enough to eliminate an excess of $\mathrm{H}_{2} \mathrm{O}_{2}$ in leaf tissue, which triggered an increase in lipidic peroxidation. Most likely, the remarkable lipid peroxidation in leaves was related to damaged thylakoid membranes within chloroplasts and the reduced photosynthesis found in C. fissilis.

The data provided by this study corroborate with those by Binotto et al., (2016) who also found partial tolerance of $C$. fissilis to flooding. However, these authors did not encounter a decrease in growth in seedlings of this species when they remained partially flooded, probably due to the shorter period of time in which plants were subjected to partial flooding (5, 15 and 20 days),

\section{CONCLUSION}

We have found that young Cedrela fissilis plants partially tolerate flooding since they developed ecophysiological changes in order to survive this condition. This species would be a suitable candidate for the re-afforestation in areas where intermittent flooding occurs, such as riverside and riparian forests.

\section{ACKNOWLEDGMENTS}

The authors would like to thank Peter E. Gibbs for the English revision.

\section{REFERENCES}

ANDRIUNAS, F; ZHANG, H.M.; XIA, X.; PATRICK, J.W.; OFFLER, C.E. Intersection of transfer cells with phloem biology-broad evolutionary trends, function, and induction. Frontiers in plant science, v. 4, p. 221, 2013.

ANTONIAZZI, A.P; BINOTTO, B.; NEUMANN, G.M.; BUDKE, J.C.; SAUSEN, T.L. Eficiência de diferentes recipientes no desenvolvimento de mudas de Cedrela fissilis Vell.(Meliaceae). Revista Brasileira de Biociências, v. I I, n. 3, P. 3|3-3|7, 2013.

ARRUDA, G.M.T.; CALBO, M.E.R. Efeitos da inundação no crescimento, trocas gasosas e porosidade radicular da carnaúba (Copernicia prunifera (Mill.) HE Moore). Acta Botanica Brasilica, v. I8, n. 2, p. 219-224, 2004.

ASADA, K, The water-water cycle in chloroplasts: scavenging of active oxygens and dissipation of excess photons. Annual review of plant biology, v. 50, n. I, p. 601-639, 1999.

BEERS, R.F.; SIZER, I.W. A spectrophotometric method for measuring the breakdown of hydrogen peroxide by catalase. Journal of biological chemistry, v. 195, n. I, p. I33-|40, 1952.
BIEMELT, S.; KEETMAN, U.; ALBRECHT, G. Re-aeration following hypoxia or anoxia leads to activation of the antioxidative defense system in roots of wheat seedlings. Plant Physiology, v. I I6, n. 2, p. 65 I-658, 1998.

BINOTTO, B.; ANTONIAZZI, A.P.; MARTA NEUMANN, G.; SAUSEN, T.L.; BUDKE, J.C. Tolerância de plântulas de Cedrela fissilis VELL. a diferentes amplitudes e intensidades de inundação. Ciência Florestal, v. 26, n. 4, p. I339-I348, 2016.

BRADFORD, M.M. A rapid and sensitive method for the quantitation of microgram quantities of protein utilizing the principle of protein-dye binding. Analytical biochemistry, v. 72, n. I-2, p. 248-254, 1976.

BOAMFA, E.I.; VERES, A.H.; RAM, P.C.; JACKSON, M.B.; REUSS, J.; HARREN, F.J.M. Kinetics of ethanol and acetaldehyde release suggest a role for acetaldehyde production in tolerance of rice seedlings to micro-aerobic conditions. Annals of Botany, v. 96, n. 4, p. 727-736, 2005.

BUEGE, J.A.; AUST, S.D. Microsomallipidperoxidation. Methods and Enzymology, v.52, n. 30, p.302-310, 1978.

COLMER, T.D.; PEDERSEN, O. Underwater photosynthesis and respiration in leaves of submerged wetland plants: gas films improve $\mathrm{CO}_{2}$ and $\mathrm{O}_{2}$ exchange. New Phytologist, v. I77, n. 4, p. 918-926, 2008.

COELHO, C.C.R.; DA SILVA, J.N.; NEVES, M. G.; DA CONCEIÇÃO, A.G.C.; DA SILVA, R.T.L; DE OLIVEIRA NETO, C.F. Aspectos ecofisiológicos e crescimento em plantas de milho ao alagamento. Revista Agroecossistemas, v. 5, n. 2, p. 4I-46, 2014.

COUTTS, M.P. Effects of waterlogging on water relations of actively-growing and dormant Sitka spruce seedlings. Annals of Botany, v. 47, n. 6, p. 747-753, I98I.

DE CARVALHO GONÇALVES, J.F;; GURGEL DE FREITAS MELO, E.; FERREIRA, M. J.; MOURA DA SILVA, C.E.; BARRONCAS GOMES, I. Crescimento, partição de biomassa e fotossíntese em plantas jovens de Genipa spruceana submetidas ao alagamento. Cerne, v. 19, n. 2, p. $193-200,2013$.

FERNER, E.; RENNENBERG, H.; KREUZWIESER, J. Effect of flooding on $\mathrm{C}$ metabolism of flood-tolerant (Quercus robur) and non-tolerant (Fagus sylvatica) tree species. Tree physiology, v. 32, n. 2, p. I35-145, 2012.

FERREIRA, C.S.; PIEDADE, M.T.F; FRANCO, A.C.; GONÇALVES, J.F.C.; JUNK, W.J. Adaptive strategies to tolerate prolonged flooding in seedlings of floodplain and upland populations of Himatanthus sucuuba, a Central Amazon tree. Aquatic Botany, v. 90, n. 3, p. 246-252, 2009.

GARCÍA-LIMONES, C.; HERVÁS, A.; NAVAS-CORTÉS, J.A.; JIMÉNEZ-DÍAZ, R.M.; TENA, M. Induction of an antioxidant enzyme system and other oxidative stress markers associated with compatible and incompatible interactions between chickpea (Cicer arietinum L.) and Fusarium oxysporum f. sp. ciceris. Physiological and molecular plant pathology, v. 6I, n. 6, p. 325-337, 2002. 
GARCÍA-CERVIGÓN, A.I.; OLANO, J.M.; VON ARX, G.; FAJARDO, A. Xylem adjusts to maintain efficiency across a steep precipitation gradient in two coexisting generalist species. Annals of Botany, v. 22, p. 46I$472,2018$.

GIANNOPOLITIS, C.N.; RIES, S.K. Superoxide dismutases: I. Occurrence in higher plants. Plant physiology, v. 59, n. 2, p. 309-314, 1977.

GRANDIS, A.; GODOI, S.; BUCKERIDGE, M.S. Respostas fisiológicas de plantas amazônicas de regiões alagadas às mudanças climáticas globais. Revista Brasileira de Botânica, v. 33, n. I, p. I-12, 2010.

HOGLAND, D.R.; ARNON, D.I. The water-culture method for growing plants without soil. California Agricultural Experiment Station, v. 347, n. 2nd edit, 1950.

INTERGOVERNMENTAL PANEL ON CLIMATE CHANGE. Climate Change 20 I4-Impacts, Adaptation and Vulnerability: Regional Aspects. Cambridge University Press, 20 I4, I 142p.

KOLB, R.M.; MEDRI, M.E.; BIANCHINI, E.; PIMENTA, J.A.; GILONI, P.C.; CORREA, G.T. Anatomia ecológica de Sebastiania commersoniana (Baillon) Smith \& Downs (Euphorbiaceae) submetida ao alagamento. Brazilian Journal of Botany, v. 21, n. 3, p. 305-312, 1998.

KOZLOWSKI, T.T.; PALLARDY, S.G. Physiology of Woody Plants, 4I I pp. Academic, 1997.

KRAUS, J.E.; ARDUIN, M. Manual básico de métodos em morfologia vegetal. Seropédica: Edur, 1997.

KREUZWIESER, J.; RENNENBERG, H. Molecular and physiological responses of trees to waterlogging stress. Plant, cell \& environment, v. 37, n. 10, p. 22452259, 2014.

JACKSON, M.B. Long-distance signalling from roots to shoots assessed the flooding story. Journal of Experimental Botany, v. 53, n. 367, p. 175-I8I, 2002.

JACKSON, M.B.; COLMER, T.D. Response and adaptation by plants to flooding stress. Annals of Botany, v. 96, n. 4, p. 50I-505, 2005.

JACKSON, M.B.; ISHIZAWA, K.; ITO, O. Evolution and mechanisms of plant tolerance to flooding stress. Annals of Botany, v. 103, p. 137-142, 2009

JOHANSEN, D.A. Plant microtechnique. McGraw-Hill Book Company, 1940. 530p.

LARRÉ, C.F.; FERNANDO, J.A.; MARINI, P.; BACARIN, M.A.; PETERS, J.A. Growth and chlorophyll a fluorescence in Erythrina crista-galli L. plants under flooding conditions. Acta physiologiae plantarum, v. 35, n. 5, p. |463-I47I, 2013.
LARRÉ, C.F.; MORAES, C.L.; BORRELLA, J.; AMARANTE, L.; DEUNER, S.; PETERS, J.A. Antioxidant activity and fermentative metabolism in the plant Erythrina crista-galli $\mathrm{L}$. under flood conditions. Semina: Ciências Agrárias, v. 37, n. 2, p. 567-580, 2016.

LIAO, C.; LIN, C. Physiological adaptation of crop plants to flooding stress. Proceedings of the National Science Council, Republic of China. Part B, Life Sciences, v. 25 , n. 3, p. I48-I57, $200 I$.

LIRA, J.M.S.; ANASTÁCIO FERREIRA, R.; DA SILVA JUNIOR, C.D.; DOS SANTOS NETO, E.M.; DA SILVA SANTANA, W. Análise de crescimento e trocas gasosas de plantas de Lonchocarpus sericeus (Poir.) DC sob alagamento para uso na recuperação de matas de ciliares. Ciência Florestal, v. 23, n. 4, p. $655-665,2013$.

LORENZI, H. Árvores brasileiras: manual de identificação e cultivo de plantas arbóreas nativas do Brasil. Nova Odessa: Plantarum, 1992.

LORETI, E.; VAN VEEN, H.; PERATA, P. Plant responses to flooding stress. Current Opinion in Plant Biology, v. 33, p. 64-7I, 2016.

MARENGO, J.A.; NOBRE, C.A.; CHOU, S.C.; TOMASELLA, J.; SAMPAIO, G.; ALVES L. M.; OBREGÓN, G.O.; SOARES, W.R.; BETTS, R.; KAY, G. Riscos das Mudanças Climáticas no Brasil: Análise conjunta Brasil-Reino Unido sobre os impactos das mudanças climáticas e do desmatamento na Amazônia. CCST/ INPE\&Met Office Hadley Centre, 20I I. 55p.

MARTINAZZO, E.G.; PERBONI, A.T.; OLIVEIRA, P.V.D.; BIANCHI, V.J.; BACARIN, M.A. Photosynthetic activity in japanese plum under water deficit and flooding. Ciência Rural, v. 43, n. I, p. 35-4I, 2013.

MEDRI, C.; PIMENTA, J.A.; RUAS, E.A.; SOUZA, L.A.; MEDRI, P.S.; SAYHUN, S.; BIANCHINNI, E.; MEDRI, M.E. O alagamento do solo afeta a sobrevivência, o crescimento e o metabolismo de Aegiphila sellowiana Cham. (Lamiaceae)?. Semina: Ciências Biológicas e da Saúde, v. 33, n. I, p. I23-134, 2012.

MEDRI, M.E.; FERREIRA, A.C.; KOLB, R.M.; BIANCHINI, E.; PIMENTA, J.A.; DAVANSO-FABRO, V.M.; MEDRI, C. Alterações morfoanatômicas em plantas de Lithraea molleoides (Vell.) Engl. submetidas ao alagamento. Acta Scientiarum. Biological Sciences, v. 29, n. I, p. I5-22, 2007.

MESSCHMIDT, A.A.; BIANCHI, V.J.; ZANANDREA, I.; MARTINAZZO, E.G.; RADMANN, E.B.; BACARIN, M.A. Trocas gasosas e atividade antioxidante de portaenxertos de Prunus spp. submetidos ao estresse seca e alagamento. Revista de la Facultad de Agronomía, La Plata, v. II4, n. I, p. 7I-8I, 20 I5.

MIELKE, M.S.; DE ALMEIDA, A.A.F.; GOMES, F.P.; AGUILAR, M.A.G.; MANGABEIRA, P.A.O. Leaf gas exchange, chlorophyll fluorescence and growth responses of Genipa americana seedlings to soil flooding. Environmental and experimental botany, v. 50, n. 3, p. 22I-23I, 2003. 
MITTLER, R. Oxidative stress, antioxidants and stress tolerance. Trends in plant science, v. 7, n. 9, p. 405-410, 2002.

NAKANO, Y.; ASADA, K. Hydrogen peroxide is scavenged by ascorbate-specific peroxidase in spinach chloroplasts. Plant and cell physiology, v. 22, n. 5, p. 867-880, 1981.

OLIVEIRA-FILHO, A.T.; JARENKOW, J.A.; RODAL, M.J.N. Floristic relationships of seasonally dry forests of eastern South America based on tree species distribution patterns. Systematics Association Special Volume, v. 69, p. 159, 2006.

OLIVEIRA, A. S.; Ferreira, C.S.; GRACIANO-RIBEIRO, D.; FRANCO, A.C. Anatomical and morphological modifications in response to flooding by six Cerrado tree species. Acta Botanica Brasilica, v. 29, n. 4, p. 478-488, 2015.

POLACIK, K.A.; MARICLE, B. R. Effects of flooding on photosynthesis and root respiration in saltcedar (Tamarix ramosissima), an invasive riparian shrub. Environmental and experimental botany, v. 89, p. 19-27, 2013.

SCANDALIOS, J.G. Oxygen stress and superoxide dismutases. Plant physiology, v. I0I, n. I, p. 7, 1993.

SEVERO, T.C.; EITELVEN, T.; LUVISON, F. Xilema: Fatores externos que influenciam no seu funcionamento, conectando o cotidiano cientifico. Revista Interdisciplinar de Ciência Aplicada, v. 2, n. 3, p. 4-9, 2017.
SINGH, A.K.; BHATTACHARYYA-PAKRASI, M.; PAKRASI, $H$. B. Identification of an atypical membrane protein involved in the formation of protein disulfide bonds in oxygenic photosynthetic organisms. Journal of Biological Chemistry, v. 283, n. 23, p. 15762-I5770, 2008.

SOUZA, T.C.D.; MAGALHÃES, P.C.; PEREIRA, F..; CASTRO, E.M.D.; SILVA JUNIOR, J.M.D.; PARENTONI, S.N. Leaf plasticity in successive selection cycles of 'Saracura' maize in response to periodic soil flooding. Pesquisa Agropecuária Brasileira, v. 45, n. I, p. 16-24, 2010.

SPERRY, J.S.; POCKMAN, W.T. Limitation of transpiration by hydraulic conductance and xylem cavitation in Betula occidentalis. Plant, Cell \& Environment, v. 16, n. 3, p. 279-287, 1993.

STRIKER, G.G. Flooding stress on plants: anatomical, morphological and physiological responses. In: Botany. v. I, p.3-28, 2012.

TAIZ, L.; ZEIGER, E.; MØLLER, I.M.; MURPHY, A. Fisiologia e desenvolvimento vegetal. 6 ed., Porto Alegre: Artmed, 2017.

The IUCN Red List of Threatened Species. Available at: $\quad$ http://dx.doi.org/ 10.2305/IUCN.UK. 1998.RLTS. T33928A9821890.en. Accessed in: 20 November 2017.

VOESENEK, L.A.C.J.; BAILEY-SERRES, J. Flood adaptive traits and processes: an overview. New Phytologist, v. 206, n. I, p. 57-73, 2015. 